\title{
Factors Influencing the Interest of Accounting Students' Career as Public Accountant: Work Environment as Moderators
}

\author{
Yerisma Welly ${ }^{1}$ \\ Christine Loist ${ }^{2}$ \\ Andy Wijaya ${ }^{3}$, \\ Sisca $^{4}$ \\ Martin Yehezkiel Sianipar ${ }^{5}$ \\ 1,2Prodi Akuntansi Sekolah Tinggi Ilmu Ekonomi Sultan Agung, Indonesia \\ 3,4,5Prodi Manajemen Sekolah Tinggi Ilmu Ekonomi Sultan Agung, Indonesia \\ *Correspondences: welly.yerisma@gmail.com
}

\begin{abstract}
This study aims to determine the effect of financial rewards, job intrinsic values, and labor market considerations on the interests of accounting students' career as public accountant and to determine the role of the work environment as moderators. This research is a type of quantitative research. The research sample is final year accounting major with total of 74 people. The sampling technique used was purposive sampling. The data analysis technique in this study used multiple regression analysis and moderated regression analysis. The results showed that there was a positive and significant influence between financial rewards, job intrinsic values, and labor market considerations on the interests of STIE Sultan Agung accounting students for a career as public accountant either simultaneously or partially. The work environment was not able to moderate the relationship between financial rewards, job intrinsic values and labor market considerations.
\end{abstract}

Keywords: $\quad$ Financial Rewards; Interest; Job Intrinsic Values; Labor Market Considerations; Public Accountant.

\section{Faktor-Faktor yang Mempengaruhi Mahasiswa Akuntansi Berkarir sebagai Akuntan Publik dengan Lingkungan Kerja sebagai Moderating}

\section{ABSTRAK}

Penelitian ini bertujuan untuk mengetahui pengaruh imbalan finansial, nilai intrinsik pekerjaan, dan pertimbangan pasar kerja terhadap minat karir mahasiswa akuntansi sebagai akuntan publik dan untuk mengetahui peran lingkungan kerja sebagai moderator. Penelitian ini merupakan jenis penelitian kuantitatif. Sampel penelitian adalah mahasiswa semester akhir jurusan akuntansi dengan jumlah 74 orang. Teknik pengambilan sampel yang digunakan adalah purposive sampling. Teknik analisis data dalam penelitian ini menggunakan analisis regresi berganda dan analisis regresi moderasi. Hasil penelitian menunjukkan bahwa terdapat pengaruh yang positif dan signifikan antara financial rewards, job intrinsik values, dan labor market concern terhadap minat mahasiswa akuntansi STIE Sultan Agung untuk berkarir sebagai akuntan publik baik secara simultan maupun parsial. Lingkungan kerja tidak mampu memoderasi hubungan antara imbalan finansial, nilai intrinsik pekerjaan dan pertimbangan pasar tenaga kerja.

KataKunci: Akuntan Publik; Minat; Nilai Intrinsik Pekerjaan; Penghargaan Finansial; Pertimbangan Pasar.

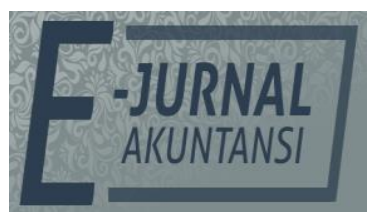

e-ISSN 2302-8556

Vol. 32 No. 2

Denpasar, Februari 2022

Hal. 371-383

DOI:

10.24843/EJA.2022.v32.i02.p07

PENGUTIPAN:

Welly, Y., Loist, C., Wijaya, A., Sisca \& Sianipar, M. Y. (2022). Factors Influencing the Interest of Accounting Students' Career as Public Accountant: Work Environment as Moderators. E-Jurnal Akuntansi, 32(2), 371-383

RIWAYAT ARTIKEL: Artikel Masuk: 16 Januari 2022 Artikel Diterima: 18 Februari 2022

Artikel dapat diakses : https://ojs.unud.ac.id/index.php/Akuntansi/index 


\section{INTRODUCTION}

One of the important aspects of a healthy adult human life is a career. The accuracy of determining and choosing a career is an important point in the journey of human life, therefore one's career contributes greatly to oneself and is the core of one's basic values and life goals. Choosing the right career according to one's interests and talents is the initial stage in career formation (Dary \& Ilyas, 2017). Career is a sequence of one's work experience over a certain period of time. Having a promising career is something that is the hope and dream of every student. If a student gets the career he aspires to, he will be able to get what he wants (Greenberg \& Robert, 2008)

Students of the STIE Sultan Agung majoring in Accounting who have completed their bachelor have at least three alternative choices in their careers. First, an undergraduate student can immediately work as employees in a company or government agency. Second, they can continue their education to the next level, namely the master degree or the third alternative option is to become an accountant (Wicaksono \& Aisyah, 2018). Accountant is a degree given to a bachelor who has studied economics majoring in accounting and has passed the Accounting Profession. Law Number 34 of 1954 concerning the Use of Accountant Degrees implies that the accountant degree can only be used by those who have completed their education from college. Someone who has earned an accountant degree can choose a career as an accountant: government accountant, corporate accountant, educator accountantor public accountant.

The public accounting profession is a party that bridges the relationship between the management and the owner or management who manages a business unit. The main activity of the public accounting profession, especially in auditing activities that aim to provide a fairness opinion on the financial statements made by the management (Baridwan, 2002). Public accountant's opinion is useful for parties related to financial statements, namely the company (management) and parties outside the company (investors, creditors, government, and society) in making decisions. One of the factors that underlies accounting students to have a career as a public accountant is their interest. The interest of accounting students can come from the students themselves for example motivation, perception, emotional and needs. And it can also come from outside the student such as the family, school and community environment. Interest is an individual's desire in a particular object that makes the individual himself feel happy with the object (Mappiare, 1982).

Interest is a feeling and an interest in something or activity, without anyone telling and arises suddenly or spontaneously, but arises as a result of participation, knowledge and habits (Rachel, 2013). Interest is also defined as a condition that occurs accompanied by feelings of pleasure associated with their own needs/desires. Interest is considered as an intermediary of motivational factors that have an impact on a behavior (Mahmud, 2008). According to Wicaksono \& Aisyah (2018), the interest of accounting students for a career as a public accountant is still low. The process that must be passed to become a public accountant is not easy, it even takes quite a long time and also costs a lot, which is the reason why this profession is still less attractive in Indonesia as evidenced by the small number of public accountants. Data from the Indonesian Institute of 
Accountants reported that overall the number of registered accountants is around 40,000, while the number of public accountants is only around 1,000. When compared with Indonesia's population of 250 million, the ratio is 1:250,000. this is very much different from the comparison in Malaysia and Singapore which are 1:23,000 and 1:5,000, respectively. This condition shows that government agencies throughout Indonesia still lack accountants of up to 25 thousand people (AKUBANK, 2021). To become a public accountant, one must first take a public accountant certification exam to obtain a license to practice as a public accountant. The Indonesian Institute of Certified Public Accountants revealed that Indonesia lacks the number of public accountants and still needs the profession in large numbers, in anticipation of the growth of the business sector. Indonesia only has a Certified Public Accountant of 4,000 people, compared to neighboring Thailand whose Gross Domestic Product is half that of Indonesia, which has a Certified Public Accountantof 12 thousand people (CNN Indonesia, 2019).

In addition to interest, other factors that influence a person to choose a career as a public accountant are financial rewards, intrinsic value of work, labor market considerations and work environment. According to (Efendi \& Abdullah, 2018), financial rewards are an important tool used by organizations to generate personal motivation that serves as the main attraction at work. According to (Kadarisman, 2012), financial rewards are one of the reasons for someone to work and are the most important reasons among others such as to achieve, affiliate with others, develop themselves, or to actualize themselves. The components of financial rewards according to (Rivai and Sagala, 2011) consist of: salaries, wages, incentives, and indirect compensation. According to Bachtiar (2002), the public accounting profession can be one of the most expensive professions because the largest source of financial rewards from public accountants has shifted from audit services to management consulting services. The public accounting profession is also a prestigious profession in Indonesia. In addition to having a bachelor's degree in accounting, prospective accountants are required to take an exam organized by the Indonesian Institute of Accountants and be registered with the Ministry of Finance to be able to practice as an accountant (Dilmy, 2002). The results of the research by Wicaksono \& Aisyah (2018) show that there is a positive and significant influence of the financial award variable on the interest in becoming a public accountant. This result is also supported by research Abbas, et al. (2020), Ledyandini, et al. (2020), and Iswahudin (2015). However, it is different from the results of research by Dary \& Ilyas (2017) which shows that financial rewards have no effect on the interest of accounting students to have a career as public accountants.

$\mathrm{H}_{1}$ : Financial rewards affect the interest of accounting students to have a career as a public accountant.

Intrinsic value is the value that is demanded for the sake of self-interest in carrying out work. Included in this value group are human desires to fulfill physical and spiritual needs, science, psychology, friendship, and religious needs (Roe, 1959). In contrast, Law (2010) argues with a different point of view that the general characteristics of professional accountants, one of which is that public accountants are a methodical way of achieving satisfaction from the work done. 
Intrinsic factors cannot be separated from the nature of the work itself and provide direct satisfaction when the work is done. Job satisfaction is an emotional attitude of someone who is pleasant and loves his job. This attitude is reflected in work morale, discipline, and work performance. Job satisfaction can be enjoyed on the job, outside the job, as well as a combination of inside and outside the job. Job satisfaction is job satisfaction that can be enjoyed at work by getting praise for work, placement, treatment, and the atmosphere of the work environment at work will prioritize work over remuneration even though remuneration is important. Intrinsic value is value that is pursued for its own sake. Included in this value is a person's desire to fulfill his physical and mental health, knowledge, inner peace, friendship, and also religious needs (Mangunhardjana, 1997).

The intrinsic value of work is a satisfaction for individuals for the work they have done, such as the value of awards, opportunities for promotion, job responsibilities, intellectual challenges, and training (Andrianti, 2001). The results of Sari (2016) research show that the intrinsic value of work in the accounting profession has a positive and significant effect on the motivation to choose a career as an accountant. So the higher the intrinsic value of the job, the higher the motivation for choosing a career as an accountant. The results of this study are supported by Lukman \& Djuniati (2015), Lutfiyah, et al. (2019) who show that the intrinsic value of work affects the interest of accounting students in a career as public accountants. This is different from Nugroho's (2014) research which shows that the intrinsic value of work does not affect the interest of accounting students in a career as public accountants.

$\mathrm{H}_{2}$ : Job intrinsic values affect the interest of accounting students to have a career as a public accountant.

Labor market consideration is one of the things that need to be considered when entering the world of work related to the job market of a profession and it also considers security, how much employment is available, the flexibility of a job related to work patterns, and the opportunity to get job promotion. According to (Wheeler, 1983), labor market considerations include four aspects, namely the availability of jobs, job security, career flexibility and promotion opportunities. In line with the opinion of (Chan, 2012) that labor market considerations include job security and the availability of job opportunities or ease of accessing job vacancies. Job security is a factor that causes the chosen career to last for a long period of time and is far from being laid off. Job security is a factor where the chosen career can last for a long time. Career is not expected to be a temporary career choice, but can continue until someone retires (Rahayu \& Setiawan, 2003). Consideration of the labor market is one of the things to consider when entering the world of work related to the job market of a profession Sari (2016). The results of Ilham, et al. (2015) research show that market considerations have a significant influence on the interest of accounting students in choosing a career as a public accountant. This is supported by the results of research by Iswahudin (2015) and Lutfiyah, et al. (2019). This is different from the results of research by Irawanti (2016), Dary \& Ilyas (2017) which show that labor market considerations have no effect on the interest of accounting students to have a career as public accountants. 
$\mathrm{H}_{3}$ : Labor market considerations affect the interest of accounting students to have a career as public accountants.

The work environment is a work atmosphere (routine, attractive, often overtime), the level of competition between employees and work pressure (Merdekawati \& Sulistyawati, 2011). According to Apriliyan (2001), competition and the amount of pressure are included in the work environment factors. According to Wijayanti (2000), the considerations in choosing a student's profession were mainly on the routine nature of the work and the work being completed quickly. In addition, all students assume that the corporate accounting profession will face routine and work that can be completed behind the desk, while the public accounting profession will face a lot of pressure and a high level of competition. According to (Alex, 2000), the work environment is something that is around the workers that can affect him in carrying out the tasks assigned. A good working environment condition is when workers can carry out their work optimally and precisely. The results of Irawanti (2016) show that the work environment has a positive effect on the interest of accounting students to have a career as a public accountant. These results are supported by the research of Wicaksono \& Aisyah (2018), Abbas, et al. (2020). In contrast to the results of research by Prasetyo (2014) which shows that the work environment does not have a significant influence on the choice of an accountant career.

$\mathrm{H}_{4}$ : The work environment is able to moderate the relationship of financial rewards, job intrinsic value and labor market considerations with the interest of accounting students to have a career as public accountants.

Based on the picture below, it can be seen the relationship between the theoretical basis and concepts used in developing the hypotheses in this study.

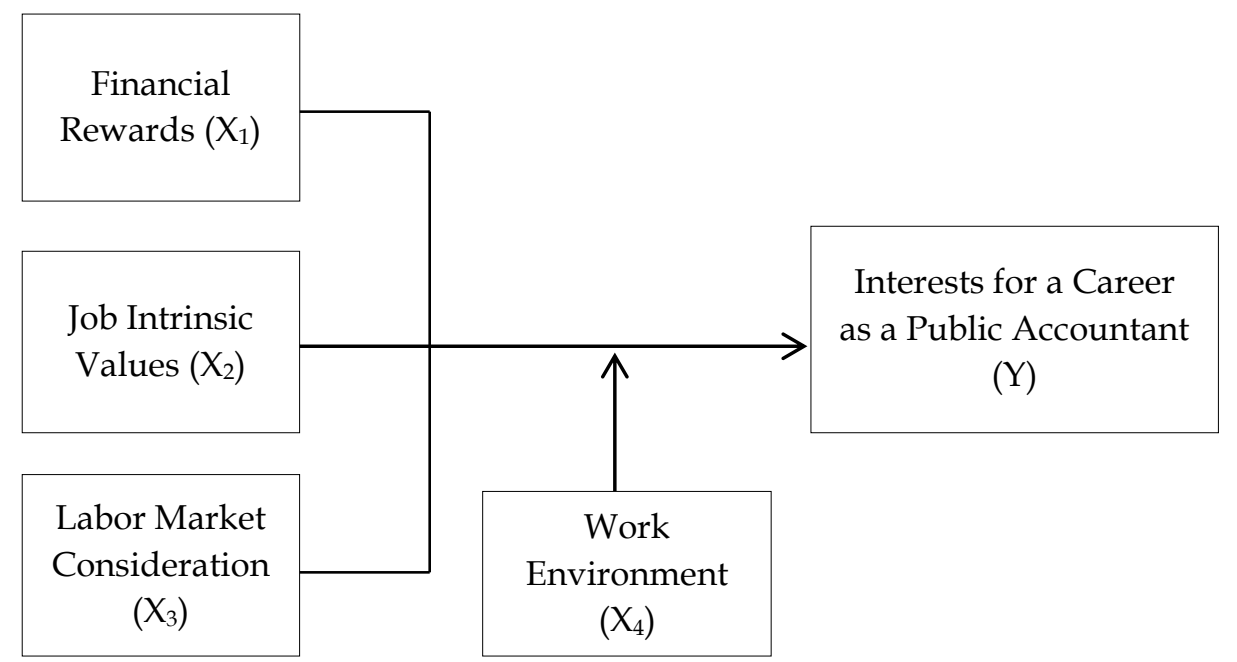

Figure 1. Framework

Source: Research Data, 2021

Due to the differences with the results of previous studies, the researchers are interested in conducting further research on the effect of financial rewards, the intrinsic value of work and labor market considerations on the interest of accounting students to have a career as public accountants by including the work environment as a moderating variable. This study was also conducted with the 
aim of seeing how much students are interested in a career as public accountants, where currently accounting graduate students are starting to lose confidence in their careers as public accountants due to feeling unable to compete with accounting graduates from neighboring countries and motivated by the requirements for becoming a public accountant, which is quite burdensome.

\section{RESEARCH METHOD}

The population in this study were Accounting Students in the Final Semester (Semester VII) at the School of Economics (STIE) Sultan Agung. This study uses primary data obtained from the results of respondents' answers through distributed questionnaires. The technique used in this research is purposive sampling method, namely taking samples with certain criteria. The sample criteria used are final semester accounting students (semester VII) at the STIE Sultan Agung who have an interest in a career as a public accountant. Respondents in this study were Accounting Students in the Final Semester (Semester VII) at the STIE Sultan Agung, totaling 207 people. There are 133 respondents who are not interested in a career as a public accountant. Then the sample of this study becomes 74 . This study uses three independent variables, namely: Financial Rewards $\left(X_{1}\right)$, Job Intrinsic Values $\left(X_{2}\right)$ and Labor Market Considerations $\left(X_{3}\right)$. And one dependent variable is the Interest of Accounting Students for a Career as a Public Accountant (Y). This study also includes one moderating variable, namely the Work Environment $\left(\mathrm{X}_{4}\right)$.

\section{RESULTS AND DISCUSSION}

The validity test will test each of the variables that will be used in this study to measure the validity or validity of a questionnaire. Overall research variables contain 44 questions from the questionnaire that must be answered by the respondents. It aims to determine the accuracy and accuracy of a research instrument in carrying out the measurement function, namely so that the data obtained can be relevant or in accordance with the purpose of the measurement. The results of the validity test obtained the $r_{\text {count }}$ value of all indicator variables $>r_{\text {critical }}$ value $(0.3)$. So it can be concluded that all indicators of the variables in this study are valid.

Reliability test is a tool to measure a questionnaire which is an indicator of research variables. A research data besides being valid must also be reliable because accuracy requires consistency. Reliability testing is done to determine the extent to which an instrument can be trusted or reliable. An instrument is said to be reliable if the instrument is used twice to measure the same symptoms and the measurement results obtained are relatively the same and consistent. Reliability with statistical test Cronchbach Alpha ( $\alpha$ ). A variable is said to be reliable if it gives a value of $>0.70$. Based on the results of the reliability test, all variables have Cronchbach Alpha $(\alpha)>0.70$. This means that the indicators of the variables in this study are reliable. 
Table 1. Normality Test Results

\begin{tabular}{|c|c|c|c|c|c|c|}
\hline & & $\begin{array}{l}\text { Financial } \\
\text { Rewards }\end{array}$ & $\begin{array}{c}\text { Job } \\
\text { Intrinsic } \\
\text { Values }\end{array}$ & $\begin{array}{l}\text { Labor Market } \\
\text { Considerations }\end{array}$ & $\begin{array}{c}\text { Work } \\
\text { Environment }\end{array}$ & Interests \\
\hline \multicolumn{2}{|l|}{$\mathrm{N}$} & 74 & 74 & 74 & 74 & 74 \\
\hline \multirow{2}{*}{$\begin{array}{l}\text { Normal } \\
\text { Parameters }{ }^{\mathrm{a}, \mathrm{b}}\end{array}$} & Mean & 30.76 & 32.04 & 33.88 & 22.42 & 40.76 \\
\hline & $\begin{array}{l}\text { Std. } \\
\text { Deviation }\end{array}$ & 6.946 & 7.499 & 7.512 & 4.599 & 10.742 \\
\hline Most & Absolute & 0.132 & 0.143 & 0.073 & 0.101 & 0.120 \\
\hline Extreme & Positive & 0.092 & 0.045 & 0.069 & 0.069 & 0.069 \\
\hline Differences & Negative & -0.132 & -0.143 & -0.073 & -0.101 & -0.120 \\
\hline \multirow{2}{*}{\multicolumn{2}{|c|}{$\begin{array}{l}\text { Kolmogorov-Smirnov Z } \\
\text { Asymp. Sig. (2-tailed) }\end{array}$}} & 1.138 & 1.227 & 0.630 & 0.867 & 1.035 \\
\hline & & 0.150 & 0.099 & 0.822 & 0.440 & 0.234 \\
\hline
\end{tabular}

Source: Research Data, 2021

A variable is said to be normal if it gives an Asymp value. Sig. (2tailed) $>0.05$. Based on Table 3, the One Sample - Kolmogorov Smirnov Test normality test above can be seen as Asymp. Sig (2-tailed) for a total $X_{1}$ (financial rewards) of 0.150 , a total of $X_{2}$ (job intrinsic values) of 0.099 , a total of $\mathrm{X}_{3}$ (labor market considerations) of 0.822 , total $\mathrm{X}_{4}$ (work environment) of 0.440 , and a total of $Y$ (interests) of 0.234.The total of all variables have an Asymp value. Sig (2-tailed) $>0.05$. Thus it can be stated that each variable data is normally distributed.

Table 2. Multiple Regression Test Results Before and After Moderation

\begin{tabular}{|c|c|c|c|c|c|c|c|}
\hline \multicolumn{4}{|c|}{ Before Moderation } & \multicolumn{4}{|c|}{ After Moderation } \\
\hline \multirow[t]{2}{*}{ Model } & \multicolumn{2}{|c|}{$\begin{array}{c}\text { Unstandardized } \\
\text { Coefficients }\end{array}$} & \multirow[t]{2}{*}{$\begin{array}{c}\text { Standardized } \\
\text { Coefficients }\end{array}$} & \multirow[t]{2}{*}{ Model } & \multicolumn{2}{|c|}{$\begin{array}{c}\text { Unstandardized } \\
\text { Coefficients }\end{array}$} & \multirow[t]{2}{*}{$\begin{array}{c}\text { Standardized } \\
\text { Coefficients }\end{array}$} \\
\hline & B & $\begin{array}{l}\text { Std. } \\
\text { Error }\end{array}$ & & & B & $\begin{array}{l}\text { Std. } \\
\text { Error }\end{array}$ & \\
\hline (Constant) & -4.821 & 3.119 & & (Constant) & 23.046 & 6.511 & \\
\hline $\mathrm{X}_{1}$ & 0.404 & 0.160 & 0.261 & $\mathrm{X}_{1} \mathrm{X}_{4}$ & 0.024 & 0.012 & 0.559 \\
\hline$X_{2}$ & 0.471 & 0.146 & 0.329 & $\mathrm{X}_{2} \mathrm{X}_{4}$ & 0.019 & 0.012 & 0.498 \\
\hline$X_{3}$ & 0.533 & 0.125 & 0.373 & $\mathrm{X}_{3} \mathrm{X}_{4}$ & 0.013 & 0.012 & 0.366 \\
\hline
\end{tabular}

Source: Research Data, 2021

Based on the results of the multiple regression test before the inclusion of the moderating variable, it was obtained $Y=-4.821+0.404 \mathrm{X}_{1}+0.471 \mathrm{X}_{2}+0.533 \mathrm{X}_{3}$, and after the inclusion of the moderating variable, it was obtained $\mathrm{Y}=23.046+$ $0.024 X_{1} X_{4}+0.019 X_{2} X_{4}+0.013 X_{3} X_{4}$. This means that both before and after the inclusion of moderating variables, the financial rewards, job intrinsic values and labor market considerations have a positive effect on the interest of accounting students of STIE Sultan Agung to have a career as public accountants.

Simultaneous test (F test) was conducted in this study to determine the statistically significant effect between the effect of financial rewards, job intrinsic values, and labor market considerations on the interest of accounting students of STIE Sultan Agung for a career as a public accountant.

Based on Table 3, the results of the F test can be seen that the F value is 74.700 with a significance of 0.000 where the significance value is smaller than alpha $(0.000<0.05)$, which means the null hypothesis is rejected. It means that the variables of financial rewards, job intrinsic values, and job market considerations 
simultaneously have a significant effect on the interest of accounting students of stie sultan agung for a career as a public accountant.

Table 3. Simultaneous Test Results (F Test)

\begin{tabular}{llccccc}
\hline Model & & $\begin{array}{c}\text { Sum of } \\
\text { Squares }\end{array}$ & Df & Mean Square & F & Sig. \\
\hline \multirow{2}{*}{1} & Regression & 6418.670 & 3 & 2139.557 & 74.700 & $0.000^{\mathrm{b}}$ \\
& Residual & 2004.952 & 70 & 28.642 & & \\
& Total & 8423.622 & 73 & & & \\
\hline
\end{tabular}

Source: Research Data, 2021

The partial test ( $\mathrm{t}$ test) aims to test whether the independent variables (financial rewards, job intrinsic values, and labor market considerations) on the dependent variable (student interests) have partial or separate effect. In seeing whether the influence of the independent variable on the dependent variable can be known by looking at the probability of significant.

Table 4. Partial Test Results (t Test)

\begin{tabular}{lccc}
\hline Model & & $\mathrm{t}$ & Sig. \\
\hline \multirow{4}{*}{1} & (Constant) & -1.546 & 0.127 \\
& $\mathrm{X}_{1}$ & 2.524 & 0.014 \\
& $\mathrm{X}_{2}$ & 3.233 & 0.002 \\
& $\mathrm{X}_{3}$ & 4.278 & 0.000 \\
\hline
\end{tabular}

Source: Research Data, 2021

Based on the results of hypothesis testing in this study, the regression coefficient for the financial rewards were 2.524, the job intrinsic values were 3.233 and the labor market consideration were 4.278 indicating the direction of the positive regression coefficient. The significance values are $0.014,0.002$, and 0.000 . At an error level (alpha) of 0.05, it can be said to have an insignificant effect because the significance value of the three variables has a value greater than the error rate $(0.014<0.05,0.002<0.05$ and $0.000<0.05)$. This means that financial rewards, job intrinsic values, and labor market considerations have a positive and significant effect on the interest of accounting students of STIE Sultan Agung to have a career as public accountants.

Table 5. Moderated Regression Analysis (MRA) Test

\begin{tabular}{cccc}
\hline Model & & $\mathrm{t}$ & Sig. \\
\hline & $($ Constant $)$ & 3.540 & 0.002 \\
1 & $\mathrm{X}_{1} \mathrm{X}_{4}$ & 1.936 & 0.057 \\
& $\mathrm{X}_{2} \mathrm{X}_{4}$ & 1.539 & 0.128 \\
& $\mathrm{X}_{3} \mathrm{X}_{4}$ & 1.092 & 0.279 \\
\hline
\end{tabular}

Source: Research Data, 2021

Based on the results of the Moderated Regression Analysis (MRA) test in Table 5, it can be seen that the work environment isnot able to moderate the relationship between financial rewards, job intrinsic values, and labor market considerations with the interest of accounting students of STIE Sultan Agung to have a career as public accountants. This is evidenced by: 1) the results of the interaction test between the work environment and financial rewards $\left(X_{1} X_{4}\right)$ which shows a significance value of 0.057 which is greater than $=0.05,2$ ) the results of the interaction test between the work environment and job intrinsic values $\left(X_{2} X_{4}\right)$ which shows a significance value of 0.128 is greater than $\left.=0.05,3\right)$ the results of the interaction test between the work environment and labor 
market considerations $\left(X_{3} X_{4}\right)$ which shows a significance value of 0.279 greater than $=0.05$. These three results indicate that $\mathrm{H}_{0}$ is rejected, meaning that the work environment is not able to moderate the relationship between financial rewards, job intrinsic values, and labor market considerations with the interest of accounting students of STIE Sultan Agung to have a career as public accountants. Table 6. Correlation and Determination Test

\begin{tabular}{cccccc}
\hline Model & $\mathrm{R}$ & R Square & $\begin{array}{c}\text { Adjusted R } \\
\text { Square }\end{array}$ & $\begin{array}{c}\text { Std. Error of the } \\
\text { Estimate }\end{array}$ & Durbin-Watson \\
\hline 1 & $0.873^{\mathrm{a}}$ & 0.762 & 0.752 & 5.352 & $0.873^{\mathrm{a}}$ \\
\hline
\end{tabular}

Source: Research Data, 2021

Based on the Table 6 results, before the moderating variableit shows that the value of $R$ is 0.873 . This conditions mean that there is a high correlation betweeninterest of accounting students of STIE Sultan Agung to have a career as public accountants with financial rewards, job intrinsic values, and labor market considerations. While the coefficient of determination ( $\mathrm{R}$ square) is $0.762(76.2 \%)$. This means that $76.2 \%$ interest of accounting students of STIE Sultan Agung to have a career as public accountants can be explained by financial rewards, job intrinsic values, and labor market considerations, while the remaining $23.8 \%$ is explained by other variables which is not explained in this study.

Based on the results of hypothesis testing, it is obtained that financial rewards have a positive and significant effect on the interest of accounting students of STIE Sultan Agung to have a career as public accountants. This can be because accounting students view the salary of the accounting profession as sufficient to meet their future needs. The results of this study support the research of Abbas, et al. (2020), Ledyandini, et al. (2020), Wicaksono \& Aisyah (2018), Iswahudin (2015). However, this is different from the findings of Dary \& Ilyas (2017) who found that there were answers from several respondents who did not agree with the statement regarding a high starting salary and this possibility caused students to want to get a variety of work experience first.

Based on the results of hypothesis testing, it is found that the job intrinsic valueshave a positive and significant effect on the interestof accounting students of STIE Sultan Agung to have a career as public accountants. These results indicate that someone who has intrinsic values in his work will reflect work morale, discipline, and work performance that results in job satisfaction such as getting praise for work results, treatment of individuals, and the atmosphere of the work environment in his work. The results of this study support the research of Lutfiyah, et al. (2019), Hermawan \& Tyas (2019), Sari (2016), Lukman \& Djuniati (2015). However, this is different from the findings of Nugroho (2014), who found the values contained in the public accounting profession were not a concern of students in choosing a career as a public accountant. Some values that can provide direct satisfaction when doing work as a public accountant do not become a driving force for the emergence of student interest in a career as a public accountant.

Based on the results of hypothesis testing, it is obtained that labor market considerations have a positive and significant effect on the interestof accounting students of STIE Sultan Agung to have a career as public accountants. That is, the public accounting profession that offers broad opportunities to develop affects 
the interest of students to choose a career as a public accountant. The results of this study support the research of Nugroho (2014), who found work as a public accounting profession that offers a sense of security (not easily laid off) and the wide opportunity to develop further increases student interest in choosing a profession as a public accountant. Labor market considerations are a relevant factor in career selection. Jobs that are guaranteed/not easy to break the employment relationship of employees will be chosen by many students. Students usually choose jobs based on the job vacancy information they get. So that jobs that are easily accessible to students are usually in great demand by students. This is also in line with the results of research by Lutfiyah, et al. (2019), Ilham, et al. (2015) and Iswahudin (2015). However, it is different from the findings of Irawanti (2016) and Dary \& Ilyas (2017) who found that there were respondents who disagreed with the statement that employment was easily accessible, job security was more secure, it was not easy to be laid off, this career could expand access and knowledge of issues current business and accounting issues and this job offers a wide choice of job types. This indicates that there is a lack of information related to the labor market considerations of public accountants and non-public accountants and the work is not considered broad.

Based on the results of the Moderated Regression Analysis (MRA), work environment is not able to moderate the relationship between financial rewards, job intrinsic values, and labor market considerations with the interest of accounting students of STIE Sultan Agung to have a career as public accountants.In this case the work environment variable is not capable of being a moderating variable or only acts as a predictor variable (independent) in the regression model that is formed.The work environment is a condition related to the working environment for employees. The work environment in this study was measured by the estimated time for social life, a good work environment, work with good leadership, and friendly and accessible employees. A negative result which means weakening indicates that a good work environment tends to cause students to reject the job or career. Generally, only people who have work experience are inclined towards work that can provide them with a work-life balance. On the other hand, students tend to have no work experience so they are less able to imagine the actual work environment they will face in the future. As a result, the work environment is even considered to have no relationship between the independent variables on the career choice of accounting students (Trista, 2016). In addition, the measurement for the work environment variable in this study is only limited to time for social life, a good work environment, work with a good leader, and employees who are friendly and able to work together. There is a possibility that students think that the work environment is not assessed based on the measurements used in this study. Therefore, in the results of this study, the work environment variable was considered not to be moderating on the career choice of accounting students.

\section{CONCLUSION}

This study found that financial rewards, job intrinsic values and labor market considerations have a positive and significant effect on the interest of accounting students of STIE Sultan Agung to have a career as public accountants 
simultaneously and partially. Another found of this study, the work environment is not able to moderate the relationship between financial rewards, job intrinsic values and labor market considerations with the interest of accounting students of STIE Sultan Agung to have a career as public accountants. Work environment variable is not capable of being a moderating variable or only acts as a predictor variable (independent) in the regression model that is formed.

This study uses a questionnaire so that the data collected only describes the student's opinion on the interest in a career as a public accountant, so that the respondent's answers cannot be controlled by researchers regarding answers that do not show the real situation. Questionnaires can also show that the resulting data has the opportunity to be biased. The possibility of bias due to differences in perception between researchers and respondents to the questions asked. Biased data will result in research conclusions that are not in accordance with the actual situation. Financial awards received by the accounting profession in the form of salaries, bonuses, allowances, to pension funds must be determined in accordance with the regulations that apply to each accounting profession and the amount given is expected to be proportional to the magnitude of the professional responsibility of an accountant. Individuals will also feel satisfaction in doing their jobs. This condition will also cause many to consider the labor market (public accountants). So that accounting students are more interested in a career as accountants and later the financial rewards they receive will be able to meet their life needs.

For further research, it is recommended to develop this research by examining other factors that influence the choice of a career as a public accountant that were not examined by the researcher. In addition, it also adds other methods outside the questionnaire to overcome the weaknesses that may exist in the questionnaire method. Further research can use a sample of all universities in Pematangsiantar City so that it can be compared the level of differences in understanding of an accounting concept between all universities in Pematangsiantar City. Future research is expected to be able to make this research not only quantitative research but also a combination of qualitative research.

\section{REFERENCES}

Abbas, D. S., Eksandy, A., \& Hakim, M. Z. (2020). Pemilihan Profesi Akuntan: Pengaruh Persepsi Penghargaan Finansial, Pelatihan Profesional, Nilai-Nilai Sosial Dan Lingkungan Kerja (Studi Pada Mahasiswa Program Studi Akuntansi Fakultas Ekonomi dan Bisnis Universitas Muhammadiyah Tangerang). COMPETITIVE Jurnal Akuntansi Dan Keuangan, 4(1), 1. https://doi.org/10.31000/c.v4i1.2218

AKUBANK. (n.d.). AKUBANK.

Alex, S. N. (2000). Manajemen Personalia: Manajemen Sumber Daya Manusia. Edisi Ketiga, Ghalia Indonesia, Jakarta.

Andrianti. (2001). Faktor-Faktor yang Mempengaruhi Mahasiswa dalam Memilih Karir sebagai Akuntan Publik dan Non Publik. Media Riset Akuntansi, Auditing dan Informasi.

Apriliyan, L. A. (2001). Faktor-Faktor yang Mempengaruhi Mahasiswa Akuntansi 
dalam Pemilihan Karir Menjadi Akuntan Publik. Universitas Diponegoro.

Bachtiar, E. (2002). The Big Five Masih Yang Termahal.

Baridwan, Zaki. (2002). Sistem Akuntansi: Penyusunan Prosedur dan Metode. Edisi 5. Yogyakarta: BPFE.

Chan, A. S. (2012). Analisis Faktor-Faktor Yang Mempengaruhi Pemilihan Karir Menjadi Akuntan Publik Oleh Mahasiswa Jurusan Akuntansi. Jurnal Ilmiah Mahasiswa Akuntansi, 1(1), 53-58. http://journal.wima.ac.id/index.php/JIMA/article/view/13

Dary, A. W., \& Ilyas, F. (2017). Pengaruh Gender, Penghargaan Finansial Dan Pertimbangan Pasar Kerja Terhadap Minat Mahasiswa Akuntansi Untuk Berkarir Menjadi Akuntan Publik Dan Non Akuntan Publik. Jurnal Akuntansi, 7(1), 51-60. https:// doi.org/10.33369/j.akuntansi.7.1.51-60

Dilmy, I. (2002). Profesi-Profesi Termahal dari Akuntan hingga Artis.

Efendi, R., \& Abdullah, T. (2018). Pengaruh Persepsi Penghargaan Finansial, Pelatihan Profesional, Nilai-nilai Sosial, dan Lingkungan Kerja terhadap Pemilihan Profesi Akuntan. Jurnal Profita: Kajian Ilmu Akuntansi, 6(7).

Greenberg, J. (2008). Robert., A. Baron. Behavior in Organizations. NinthEdition. New Jersey: Prentice Hall.

Hermawan, S., \& Tyas, F. I. W. N. (2019). Pengaruh Nilai Intrinsik, Parental Influence, dan Persepsi Mahasiswa dengan Pendekatan Theory Karier Anne Roe terhadap Pemilihan Karir sebagai Akuntan Publik bagi Mahasiswa Akuntansi Universitas Airlangga Surabaya. JABE (Journal of Applied Business and Economic), 5(2), 112. https:// doi.org/10.30998/jabe.v5i2.2111

Ilham, E., Hasan, A., \& Sari, M. D. (2015). Pengaruh Motivasi, Persepsi dan Pertimbangan Pasar Kerja terhadap Minat Mahasiswa Akuntansi Ppak dalam Pemilihan Karir sebagai Akuntan Publik (Study Empiris pada Universitas Ppak di Sumatra). Riau University.

Indonesia, C. (n.d.). Indonesia Disebut Krisis Akuntan Publik. https://www.cnnindonesia.com/ekonomi/20190125132742-92-

363792/indonesia-disebut-krisis-akuntan-publik.

Irawanti, N. F. (2016). Faktor-Faktor yang Memengaruhi Minat Mahasiswa Akuntansi Untuk Berkarir Menjadi Akuntan Publik. Universitas Atma Jaya Makassar.

Iswahudin, M. (2015). Pengaruh Penghargaan Finansial dan Pertimbangan Pasar Kerja Terhadap Pemilihan Profesi sebagai Akuntan Profesional (Studi Kasus pada Mahasiswa Akuntansi Universitas Negeri Yogyakarta).

Kadarisman, M. (2012). Manajemen kompensasi. Jakarta: Rajawali Pers.

Law, P. K. (2010). A theory of reasoned action model of accounting students' career choice in public accounting practices in the post-Enron. Journal of Applied Accounting Research.

Ledyandini, S., Hambali, I. R., \& Wuryandini, A. R. (2020). Gender, Penghargaan Finansial, Pengakuan Profesional Terhadap Pemilihan Karir Sebagai Profesi Akuntan Pada Mahasiswa Di PT Provinsi Gorontalo. Jambura Accounting Review, 1(1), 22-35.

Lukman, H., \& Djuniati, C. (2015). Pengaruh Nilai Intrinsik, Gender, Parental Influence, Persepsi Mahasiswa dan Pertimbangan Pasar Kerja dengan Pendekatan Theory Of Reasoned Action Model Terhadap Pemilihan Karir sebagai Akuntan Publik Bagi Mahasiswa Perguruan Tinggi Swasta di 
Jakarta. Proceding Simposium Nasional Akuntansi, 18.

Lutfiyah, Q., Diana, N., \& Mawardi, M. C. (2019). Pengaruh Nilai Intrinsik Pekerjaan, Persepsi Penghasilan Dan Pertimbangan Pasar Kerja Terhadap Minat Mahasiswa Akuntansi Untuk Berkarir Sebagai Akuntan Publik (Studi Kasus Pada Mahasiswa Akuntansi Feb Unisma Dan Fe Uin Malang). E-Jra, $8(5), 1-8$.

Mahmud, A. (2008). Pengaruh Motivasi Terhadap Minat Mahasiswa Untuk Mengikuti Pendidikan Profesi. Dinamika Pendidikan, 3(1).

Mangunhardjana, A. (1997). Isme-Isme dalam Etika dari A-Z. Yogyakarta: Kanisius, 186-187.

Mappiare, A. (1982). Psikologi Remaja.

Merdekawati, D. P., \& Sulistyawati, A. I. (2011). Faktor-faktor yang mempengaruhi pemilihan karir akuntan publik dan non akuntan publik. Jurnal Ilmiah Aset, 13(1), 9-19.

Nugroho, A. (2014). Analisis Faktor-Faktor Yang Memengaruhi Minat Mahasiswa Akuntansi Untuk Berkarir Menjadi Akuntan Publik (Studi Kasus Pada Universitas Sebelas Maret Surakarta). Universitas Muhammadiyah Surakarta.

Prasetyo, H. (2014). Kajian Persepsi Pemilihan Karir Akuntan. Universitas Dian Nuswantoro.

Rachel, C. (2013). Pengaruh Faktor Eksternal dan Internal Terhadap Pemilihan Kair Mahasiswa Akuntansi Sebagai Akuntan Publik (Studi Empiris pada Mahasiswa Akuntansi Universitas Riau). Universitas Riau.

Rahayu, S., \& Setiawan, E. A. S. D. (2003). Persepsi Mahasiswa Akuntansi Mengenai Faktor-Faktor Yang Mempengaruhi Pemilihan Karir. Simposium Nasional Akuntansi VI.

Rivai, V., \& Sagala, E. J. (2011). Manajemen Sumber Daya Manusia untuk Perusahaan, edk 2. Rajawali Pers, Jakarta.

Roe, A. (1959). The Psychological of Occupations. Arizona, New York, USA: John Wiley \& Sons.

Sari, L. K. (2016). Pengaruh Nilai Intrinsik Pekerjaan, Lingkungan Kerja, Dan Pertimbangan Pasar Kerja Terhadap Motivasi Pemilihan Karier Sebagai Akuntan (Studi Kasus Pada Mahasiswa Program Studi Akuntansi Universitas Negeri Yogyakarta). Skripsi. Yogyakarta: Fakultas Ekonomi Universitas Negeri Yogyakarta.

Trista, L. (2016). Analisis Faktor-Faktor yang Mempengaruhi Pemilihan Karir Mahasiswa Akuntansi dengan Lingkungan Kerja sebagai Variabel Moderating.

Wheeler, K. G. (1983). Perceptions of labor market variables by college students in business, education, and psychology. Journal of Vocational Behavior, 22(1), $1-11$.

Wicaksono, Y., \& Aisyah, M. N. (2018). Pengaruh Penghargaan Finansial, Lingkungan Kerja, Dan Tipe Kepribadian Terhadap Minat Mahasiswa Akuntansi Untuk Berkarier Menjadi Akuntan Publik. Jurnal Profita: Kajian Ilmu Akuntansi, 6(3).

Wijayanti, L. E. (2000). Faktor-faktor yang Mempengaruhi Pilihan Karir Mahasiswa Akuntansi. Universitas Gadjah Mada. 